\title{
Aussies, Rogues and Slackers: Simon Hanselmann's Megg, Mogg and Owl Comics as Contemporary Instances of Rogue Literature
}

\section{ABSTRACT}

This paper examines the Megg, Mogg and Owl stories of Simon Hanselmann, an Australian artist whose serialized comics both depict acts of contemporary roguery committed by a group of friends in an inner city sharehouse and test the generic limits of its own storytelling conventions, thereby becoming contemporary instances of "rogue texts." The paper positions the adventures of Megg, a witch, Mogg, her familiar, Owl, their housemate, and associated characters including Booger and Werewolf Jones as contemporary variations of both the Australian genre of grunge fiction and the broad international tradition of rogue literature. It shows how Megg, Mogg, Owl and their friends use the structure of the sharehouse to make their own rules, undertake illegal behaviour, and respond to the strictures of mainstream society, which alongside legal restrictions include normative restrictions on gender and behaviour. It shows the sharehouse as a response to their economic, as well as cultural and social conditions. The paper then shows how Megg and particularly Owl come up against the limitations of the permissiveness and apparent security of their "rogue" society, and respond by beginning to "go rogue" from the group. Meanwhile, the text itself, rather than advancing through time, goes over the same chronology and reinscribes it from new angles, becoming revisionist and re-creative, perhaps behaving roguishly against the affordances of episodic, vignette form. The paper argues that Simon Hanselmann's Megg, Mogg and Owl comics can be understood as contemporary rogue texts, showing characters responding to social and generic limits and expressing them through a restless and innovative comics text.

Keywords: comics, grunge fiction, rogue literature, sharehouses, serialized storytelling. 


\section{Introduction: Simon Hanselmann’s Megg, Mogg and Owl COMICS}

Simon Hanselmann is a prolific Australian comics-maker whose work chronicles the fictive lives of Megg, Mogg and Owl: young depressives sharing a house and experimenting with sex, sexuality, substances and behavioural norms, a "caustic, abusive ensemble of millennial burn-outs" (Brown). This paper analyzes the Megg, Mogg and Owl comics, funny animal narratives that depict a central group of non-conformistsexplicitly positioned at the fringes of society, but whose characters and moralities are steadfastly concerned with creatively exploring boundaries of acceptable behaviour rather than with being outright deplorable. Still, as time passes in these comics, the reader's understanding of the characters develops; characters change; and the work itself comes to deviate from the expectations it establishes in the reader, troubling expectations of what kind of story is being read.

As such, while the comic is not formally a work of rogue literaturewhich would have required its publication some three hundred years ago, into an environment with different understandings of subjectivity, publication and audience, among others-it suggests new configurations of the reinvigorated rogue, both a text about a group of persons who behave roguishly and a text conducting a meaningful act of roguery against genre, expectation, form. As characters change, so does the storytelling method; the story is typically composed of short vignettes which begin to chafe against their own formal limitations. While, like seventeeth-century rogue literature, the text surveys and depicts "low life and all forms of deceitful practices" (Mayall 56), and highlights much that's vital and compelling about these practices themselves; it also allows its characters to grow away from those behaviours and out of the textual and generic structures that much of the comic spends depicting them so well.

The Megg, Mogg and Owl stories are sharehouse stories with sitcom rhythms; they double as ersatz delivery systems for complex, evolving and multifaceted tales of transgressive behaviours, especially investigating the dynamics of friendships and romantic partnerships that exist outside normative categories. Through both continuing and undermining traditions of slackerdom, embodying disinterested thinking and pushing past the boundaries of conformity and containment, they continue a conversation about changing masculinities in Australia begun in prose fiction as "grunge literature" in the 1990s. Ultimately, they are queer and probing narratives that explore the lived experience of mental illness and the consequences of trauma, complicating ideas of the citizen as criminal, the citizen as romantic, and the criminal as a force for 
either social good or ill; as such, this paper argues that the literature of roguery provides an instructive lens through which to understand this contemporary Australian comic.

\section{There's No Place Like Home: Megg, Mogg and Owl as Contemporary Rogues}

Meg and Mog are characters from a series of children's books published in the UK by Helen Nicoll and Jan Pienkowski (1972), but Hanselmann's stories, in the artist's words, have "zero similarities" to the children's books beyond surface influence (qtd. in Collins).

Megg is a green-skinned witch. Mogg, a cat, is both her lover and her familiar; until the end of the three main books' chronologies, they share a house with Owl, an anthropomorphized owl, who is more anxious to obtain markers of traditional adulthood than Megg and Mogg, bongsmoking slackers who often "gleefully sabotage [Owl's] anxious gestures towards romantic or professional normality" (Randle).

The most significant secondary character in their "desolate suburban world” (Reith) is Werewolf Jones, a burnout "party bro" who's into more serious forms of criminal behaviour than the protagonists (for instance, using heroin), who has two kids, also werewolves, Diesel and Jaxon, and who is more "up" for wild fun than any of them, as well as more liable to steer that fun towards a dark and disturbing outcome. He is often the catalyst of individual vignettes, especially the stories longer than a single page that take the characters away from the couch in their sharehouse and into the outside world (for instance, a theme park). Their milieu also includes occasional characters, including Booger, a "gender-illusionist boogeyman" (Hanselmann qtd. in Reith) with mottled green skin who presented as male when the characters all met in high school and presents as female in stories set in the present day.

The Megg, Mogg and Owl stories are published in a variety of formats and through a variety of sources: bound hardbacks from art and comics publishers, scans posted on Tumblr, self-published zines, vignettes in magazines, and other forms of digital and physical ephemera. In this paper, I limit the study to the three widely available collections published in English through Fantagraphics: Megahex (2014), Megg \& Mogg in Amsterdam (And Other Stories) (2016) and One More Year (2017). All three collections cover roughly the same short span of time, with the latter two volumes filling out the main narrative with extra episodes.

In these episodes the characters exhibit alcoholism, drug addiction, codependence, promiscuity, hypocrisy, cruelty and laziness. They perform 
a litany of misdeeds, from the clearly illegal to the questionably tasteful: these include misleading employers, cheating others, stealing, spreading bad information, corrupting others, having sex in public, defecating in public, spying on change rooms, breaking promises, and basic neglect of romantic, domestic and personal responsibilities. For the most partwith the crucial exception of an instance of sexual assault, discussed in the following section-these deviant behaviours are charming, as well as cringe-inducing. They may frequently either offend or revolt the reader, but rarely will they do both-instead, like the literature of roguery, "offering an irresistible combination of the exotic and alluring with the picaresque and threatening" (Mayall 65).

In large part, they offer the simple pleasure of watching young people push boundaries. Despite the comics' large international readership, they cannot be decoupled from the Australian context of grunge literature, with which they share many characteristics. Referring to a boom in Australian fiction in the 1990s (with plenty of precursors), novels published (or received) as grunge literature promised to be raw, disturbing, compelling, unflinching and "real," and proved popular with a "previously unmapped demographic of sub-thirty year old readers" (Leishman 94). Key works of grunge fiction suggested or promised to chart "the territory of Australia's inner cities and the disenfranchised people who lived there; gritty, dirty, real existences, eked out in a world of disintegrating futures where the only relief from ever-present boredom was through a nihilistic pursuit of sex, violence, drugs and alcohol," with notions of realism being "compounded" by the knowledge that many grunge novels were debuts (Leishman 94). As a commercial category, grunge fiction can be linked to related art forms marketed towards this demographic in the 1990s, including grunge music; as an artistic category, it has been linked to dirty realism, to Australian social protest literature of the 1930s, and to $19^{\text {th }}$ century French decadence literature (Vernay 152).

For many Australian readers, simply setting a comic in a sharehouse suggests a relationship to grunge literature. Since the 1960s, when it became common practice for young Australians to rent houses together in cities, the idea of the sharehouse has both been fixed in the cultural imagination as a site of experimentation and youth, and according to Griffin, an idea that has tracked changes and upheavals in society (21). In the present decade, the sharehouse is considered "a place to become yourself in ways you hadn't expected" (22) with the economic reality of sharehouses (not everyone who lives in sharehouses would choose to live there) mixing with social benefits and a sense of imaginative possibilityaccess to new people and attendant opportunities, as well as freedom from the family. 
As a crossroads, a private space, a subcultural space, and a space of conversation, the Australian sharehouse acts as a natural home for contemporary popular visions of roguery; and indeed Hanselmann's stories, which often take the form of a single page vignette, are ideally suited to chronicling it. Just as past instances of rogue literature might collect observations of wayfaring communities and concretize them as shorter-form anecdotes, the episodic structure of Hanselmann's work feels fragmented, observed, overheard, recalling Griffin's suggestion that "the true sharehousehold art form might be the oral tradition that's sprung from it": "After all, the stories people tell about sharehouses are how the sharehouse lives on as a dream. Part grimy kitchen-sink prurience, part distinctive oral history form, they can be educational screeds, implicit slices of moral instruction, and rich, weird lamentation" (23). If the vignettes aren't filled with the dictions of the "market place, prison and brothel," then, like instances of rogue literature, they well contain "a skilled literary reconstruction of the underworld cant based on speech movement" (Kleparski and Pietrzykowska 128).

If Hanselmann's texts eventually show the characters pushing against the boundaries of their social and economic lives, sharehouse life is initially depicted as a refuge, a place for the characters to be themselves and escape from mainstream society - a place that requires different attitudes towards work, the law, gender and money. According to Leishman, "Australian narratives have traditionally represented a particular type of individual, who has been defined in terms of his relationship to an uncompromising and brutal landscape"; for this individual, like the landscape, social injustices are not escaped, but endured (97). They are outlaws, but also social avengers, as when Megg sees a trucker making a lewd gesture, leans out the window of a car, and slashes his tires (Hanselmann, Amsterdam 10). Time and again, the Megg, Mogg and Owl stories show life outside the sharehouse as an ordeal.

Regarding work, neither Megg nor Mogg have jobs; Werewolf Jones sells felt hats on Etsy. Regarding the law, all the characters use drugs seemingly daily, and sometimes orgiastically. Regarding gender, in one scene, Megg is shown putting on makeup, smoking from a bong, then checking her possessions before leaving the house: she goes through a pouch of tobacco to check that five cigarettes are pre-rolled, then goes through her handbag, checking that she has " $[\mathrm{b}]$ ook, crystals, lighter, keys, knife, purse, phone, gloves, travelcard, pen, tobacco, travel joints, rum” (Hanselmann, One More Year 162). Much like Joan Didion's famous list of things to pack and carry when leaving town on a reporting mission-mohair throw, typewriter, 2 legal pads and pens, files, house key (Didion 34-35)this process suggests that being a woman requires a kind of artillery, let 
alone a depressed, unemployed woman who doesn't own a home. In one scene Booger, who once presented as male but now presents as female, goes to try on women's clothes in the changing rooms at a boutique and the attendant says: 'Uh, sorry. . . We uh. . . / We don't allow men in the lady's change rooms" (Hanselmann, Amsterdam 52). Megg comes to her defence and calls the attendant a "hate monger" and a "rude bitch"; "Oh, it happens all the time. ..." says Booger (52). Regarding money, at one point Megg suggests the three housemates "just stop paying rent altogether. . . / and see what happens...” (Hanselmann, One More Year 28). "Everything will be okay," she assures Owl: she's going to start making and selling ceramics, and Mogg will sell some of his CDs (29).

They are not supported by traditional family structures. At one point Megg gets a text from her mother and is excited to hear from her; yet in the subsequent phone call, her mother asks to borrow fifty dollars, which is clearly an amount Megg cannot afford (she still says okay) (Hanselmann, One More Year 153-54). Yet they are (mostly) united by an aggressive attitude towards financial success. In a one-page strip called "Young Professionals," Megg, Mogg, Owl and Werewolf Jones are shown having a picnic in a park. Megg says: "Man, what a classy afternoon! / It was nice to get out of the house" (Hanselmann, Amsterdam 64). Mogg says: "Yeah, good idea, Megg" (though an asterisked info box corrects him: "Actually Owl's idea") (64). Megg says: "We should do classy picnics more often. .." (64). "Yeah. I had a good time. / Top class!” says Werewolf Jones, who is pricking himself with a needle while the others (except Owl) smoke weed (64).

As this scene suggests, Owl is the character nearest to ideas of the citizen supported and encouraged by mainstream society. Indeed, his failure to belong to both mainstream society, in which he yearns to play a role, and to the culture of the sharehouse, to which he cannot belong thanks to steps he takes to better his lot, is a frequent source of derision from the other characters, especially Mogg the cat. In one scene Owl has a "ladyfriend," a "trainee policewoman," coming over to the house and seems embarrassed by Megg and Mogg. "She's very 'straight," Owl explains (Hanselmann, Megabex 53). "What?! Why is this woman coming to our house?! / Why can't you just fuck her in the woods like a real man?” says Megg (53). Owl begs Megg and Mogg to be on their best behaviour: "This is really important! I need her to think I'm a normal guy ... A nice normal guy with a respectable career \& good health" (53). Megg replies: "I don't think 'call centre douche' counts as a respectable career” (53).

At one stage, Owl discovers he is paying $80 \%$ of the rent. “... Yeah...you have your own room," says Mogg; "That's fair” (Hanselmann, One More 
Year 6). She adds: "My parents only give me a certain amount of money, Owl ... I can't afford the type of fancy rent that you pay" (8). Even when Owl gets a "dream job," the triumph is a tragedy: "they've agreed to take me on part time on a trial basis" (Hanselmann, Megabex 182).

Yet the Megg, Mogg and Owl stories don't so much depict individual acts of outsiderdom as the operations of a counter-group: like instances of rogue literature, they depict "a society within a society, or rather outside it, an anti-society with its own rules and rulers" (Salgādo 23). True, Owl is a black sheep, but he's also depended on and treasured (if never supported, and in some cases actively harmed-the eventual catalyst for change). While no two characters display as much explicit and ongoing affection as Megg and Mogg, whose romantic and sexual relationship is as habitual and comfortable as it is frequently strained, the stories offer many opportunities for characters to express some form of love for one another. When Megg and Mogg are in Amsterdam, having a terrible time without their antidepressants, and learn that Owl is coming too, Megg says: "Owl?! / Oh, thank god! / . . No offence. . . / But thank god" (Hanselmann, Amsterdam 127). They treat Owl cruelly, but depend on him. In another scene, Werewolf Jones hears his son Diesel level a repulsive slur against Owl, and is shocked to learn that he's only repeating something Werewolf Jones said in the first place. Werewolf Jones explains: "Boys, Owl isn't so bad. . . He's just a bit of an asshole narc. .." (Hanselmann, Amsterdam, 149). For Werewolf Jones, this is a serious compliment; the slur is something Werewolf Jones believes he is allowed to say within the context of his debatable affection.

Indeed, even Werewolf Jones is bound to the group because he suffers from mental illness, having a "disgusting person freakout" at the same time as Megg is having her daily "body freakout" (Hanselmann, Amsterdam 115) (fig. 1).

Despite how often the characters harm each other and seem to put their friendships in jeopardy, it's clear they are highly valued. At one point, Werewolf Jones buys paint to paint the house (where he doesn't live) and says: "We're a family! / We're at our best together!" (Hanselmann, Amsterdam 157). For all the deviant behaviour depicted in the stories, perhaps the most radical is the insistence on the value of friendship groups, which stands in contrast to the rugged idea of the (white, straight) Australian man pitting himself against the landscape; this also sets Hanselmann's work apart somewhat from the tradition of grunge fiction, which often focuses on the romantic and the individual more than the group. What matters to Hanselmann's characters is not the laws or standards of the culture or the land, but those set up within the sharehouse by example and agreement. 
Ronnie Scott
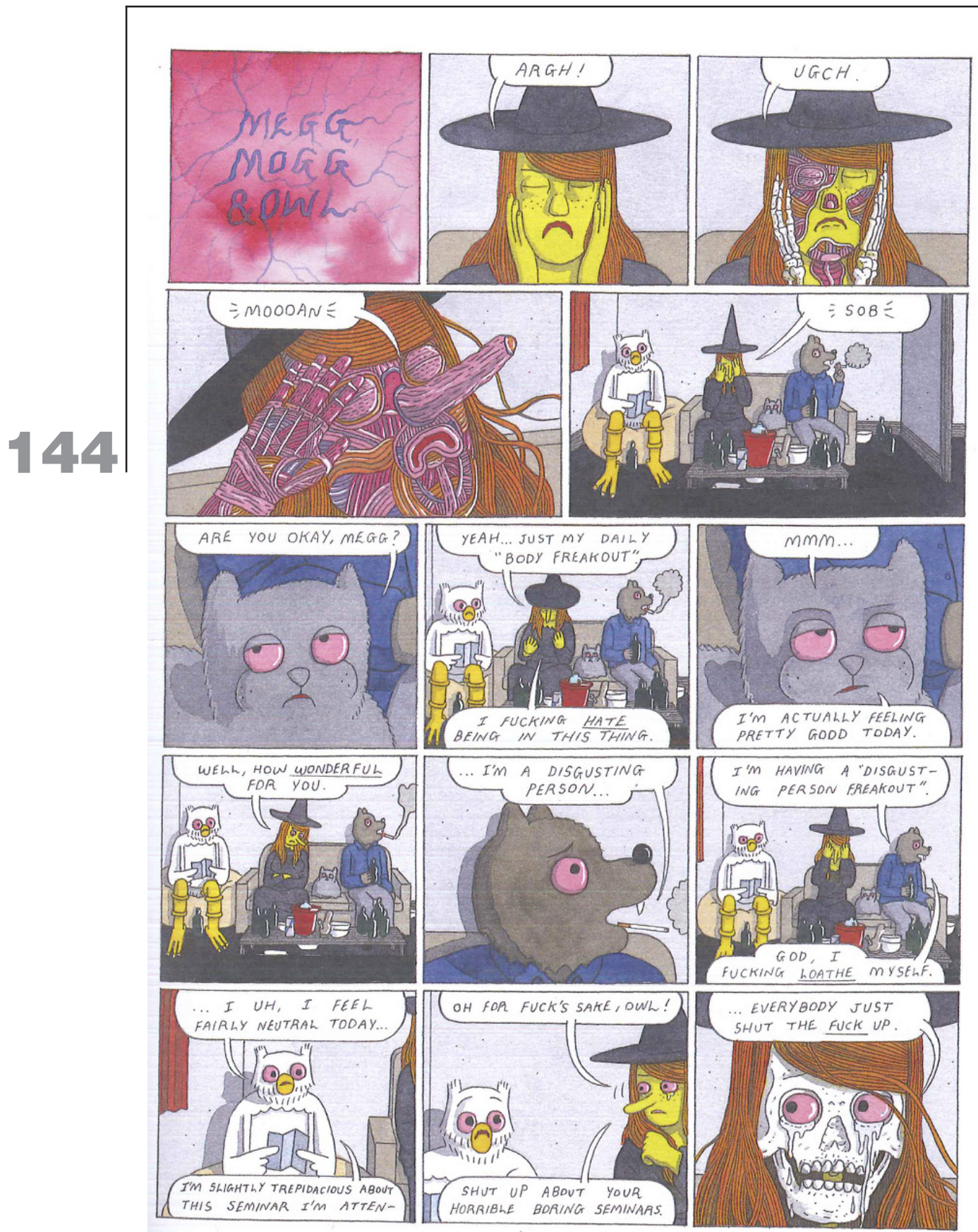

Fig. 1. Hanselmann, Simon. Megg \& Mogg in Amsterdam (And Other Stories). Fantagraphics, 2016. 115. Used by permission of Fantagraphics Books. 


\section{The Limits of the Sharehouse: Going Rogue From THE GROUP}

If rogue literature aims both to "satisfy the ever-present desire for the sensational" and "forewarn honest people against social parasites" (Kleparski and Pietrzykowska 123), the Megg, Mogg and Owl stories constantly ask the reader to reevaluate their understanding of what they've just read. What from one angle may be a sensational antic purposed towards friendship bonding and asserting the value of group, from another angle may be, of course, dangerous and criminal. The angles can also differ within and among participants. The structure of the comic begins to complicate and move towards change, when antics that may be appealing precisely because they are criminal are shown to affect characters to the point of trauma.

Among the Megg, Mogg and Owl stories' relationships to popular and literary genres is a skeptical but deep-rooted relationship to the network sitcom. In interviews Hanselmann has claimed TV is "a bigger influence on his work than most comics": "I've learned all of my most valuable lessons from Seinfeld, The Simpsons and Sabrina the Teenage Witch" (qtd. in Reith). Elsewhere he states the Megg, Mogg and Owl stories are "just a sitcom on paper" (qtd. in Nadel). When they appear in the comic, references to sitcoms are pointed and even critical, as when we briefly see Mogg watching a sitcom that resembles Friends on TV: "Monica, your OCD is spiralling out of control. ..," says one character (Hanselmann, One More Year 109). "We're legitimately concerned. This isn't funny" (109). This stands in contrast to a comic where the humourous beats are periodically broken up with depictions of mental illness that go beyond gritty comic book "darkness," even crossing into formal experiments that literalize the feeling of mental illness (as in fig. 1).

Yet it's the episodic form of this comic that most closely resembles the sitcom, not only in its method of doling out story piece by piece but in the necessity of setting up comedic beats that either deliver on or productively subvert expectations set up in previous episodes or within scenes. As Nadel notes (after Frank Santoro), the regular grid of most of Hanselmann's pages establishes expectations in ways that closely match the pacing of a sitcom scene. Many stories open with the characters sitting on a ubiquitous sharehouse couch, with a bong on the coffee table, pizza scraps and empty drinks; indeed we get this so often that every other kind of scene feels like an excursion, a special variation on the theme. These rhythms feel secure and serve as a visual cue that relationships will reset as if through "inconsumable" time (Eco 16). They also serve as spaces of security for the characters, who experience the world outside the sharehouse as difficult. 
Over time, though, the characters start to push against these structures, and a text about contemporary roguery starts to behave as a contemporary rogue text. For all its benefits, the group is not sufficient to support its constituents' needs; moreover the structure of the comic, with its sitcom beats and implied reset procedures, is not sufficient to support the growth of individuals, which is necessary for characters who exist in time. In a reliable world, a reliable home, and as part of a reliable group, roguery is appealing for its "colour, excitement, energy, freedom and lack of restraint" (Mayall 77). However, the approach has limits; and to different extents, the characters of both Megg and Owl show how the sense of isolation they feel in the world outside the group might be felt just as acutely within the group.

If Megg feels embattled as a woman outside the sharehouse, she is also isolated in the house she shares with Mogg (a male cat) and Owl. As Murrie points out, contextualizing the phenomenon of grunge fiction, male friendship, "mateship," "has traditionally been a defining feature of dominant masculinity in Australia and the mechanism by which masculinity is both authorized and acknowledged in the individual male subject" (171). Despite Megg's gender (and the anthropomorphic status of the characters) this particular group is masculinist, both self-policing and self-authorizing, "an ideal vehicle for the maintenance of hierarchical power relations" (171). If masculinity after grunge literature is "marooned," "confused, contradictory, exhausted and disempowered," incoherent (176), then rogue spaces like sharehouses—and closed friendship groups-are spaces where this can either be challenged or remain intact.

When Owl and Werewolf Jones try to get Megg to play a video game in which one level is called "Feminist Rally Massacre," Megg has Booger take her to a "crafternoon" (Hanselmann, Amsterdam 72). There, three women named Emma, Clarity and Azura make vegan lasagne and spout apparently vague or unlistenable leftist values: "Basic wages blah blah blah," "Blah blah blah detention centers," "Blah blah blah the refugees," "Discrimination blah blah blah," "Blah blah blah privilege," "Blah blah blah yarn bombing" (Hanselmann, Amsterdam 75). Megg and Booger offend the women by chainsmoking and peeing in the back yard; Megg is contemptuous of these "flaccid hippies" emphasis on "playing" (80). She goes back to the male-dominated sharehouse and her cat/familiar/boyfriend, but because she's had an awful experience in the outside world, the return reads as an act of resignation.

In more and more of Megg's vignettes, particularly those spent alone with Mogg, Mogg expresses contentment with their up-and-down relationship while Megg expresses or hides dissatisfaction and fear of being stuck. One night the two of them are looking at the moon and Mogg says: "I never want to leave 'drug world.' / . . Can we never leave?" (Hanselmann, One More Year 168). “. . No ...,” says Megg (168). “'One 
more year'” (168; fig. 2). Because Megg's dialogue appears in scare quotes, it suggests this deadline has been discussed more than once.
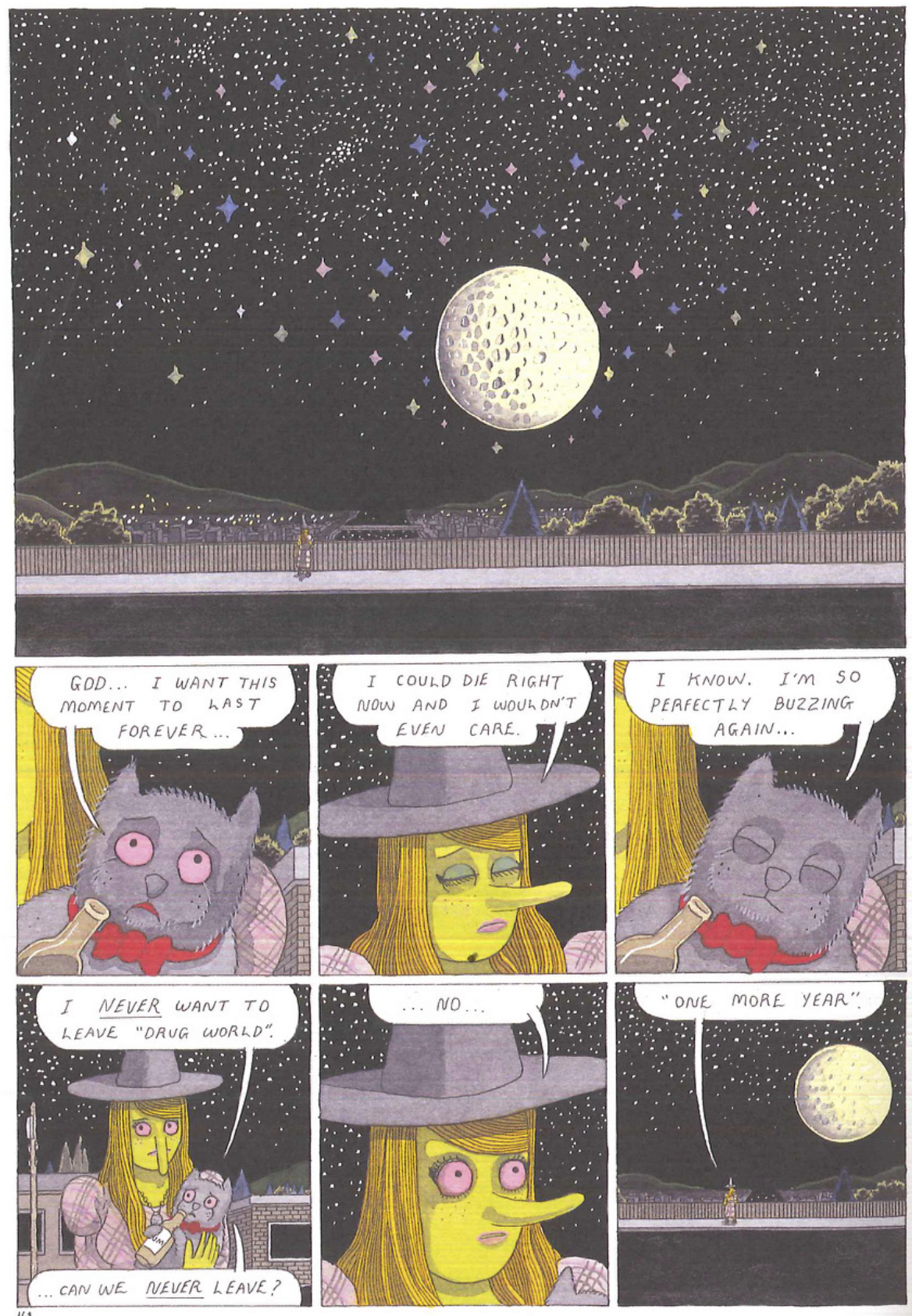

Fig. 2. Hanselmann, Simon. One More Year. Fantagraphics, 2017. 168. Used by permission of Fantagraphics Books. 
However, it's Owl who demonstrates the clearest need to go rogue from the group, and thereby most starkly reveals the limitations of the episodic form for allowing growth of characters. Owl is constantly demeaned, humiliated and disrespected by Megg, Mogg and Werewolf Jones, from the group declining to clean up the house on a day to day basis (Hanselmann, Amsterdam 98; fig. 3) to Megg spending money he's lent her for emergency dental care on alcohol, a Nintendo, a dress and a pallet of bananas (Hanselmann, Amsterdam 41).

These scenes exhibit considerable variance in tone, and are as likely to develop character as they are to set up a joke. Even so, the overall outcome is usually humorous, with the most serious moments in the Megg, Mogg and Owl stories being centred around, for instance, mental illness rather than sharehouse pranks.

A clear exception is a "prank" in which Megg, Mogg and Werewolf Jones sexually assault Owl. Specifically, they take him to a house promising a "birthday surprise" and then pretend to rape him, both through stating their intention and through physical violence and groping, before revealing it was all a trick and singing "Hip hip hooray!" (Hanselmann, Megabex 68-72).

Reading this scene for the first time is confusing; subsequent reads are sickening. Indeed, the scene was complicated in both conception and reception. In the version first published, Mogg tells Owl: "We're going to rape you"; in the collected edition, the line reads "We're going to do you" (68). According to Hanselmann, "it made more sense (for later in the story) for Megg and Mogg to not really fully know what they were doing"; some online commenters accused him of glossing over sexual assault, while others accused him of bowing to political correctness (Reith). Later in the story, Megg and Mogg are surprised that Owl has been traumatized by the episode. "It was sexual assault," he explains (Hanselmann, Megahex 73). "Don't say that. That makes us sound horrible. ..," says Megg, also claiming it was Werewolf Jones' idea and that he said it would be funny (73). They apologize. "Please don't move out!” says Megg (73). For Hanselmann, the awfulness of the scene is the point: "People are horrible. People are cruel. People are abused. Social circles, especially in small towns, can get fucking nasty" (qtd. in Reith).

Towards the end of the chronology of the Megg, Mogg and Owl stories published in the three Fantagraphics books, although the plots remain slow-moving and often revisit old territory, the reader begins to spend slightly more time with Owl away from the group, as in a scene showing Owl responding to New Year's Eve fireworks with seemingly ambiguous feelings, perhaps loss or confusion (Hanselmann, Megabex 194). Afterwards, he comes home to the sharehouse and sees others 

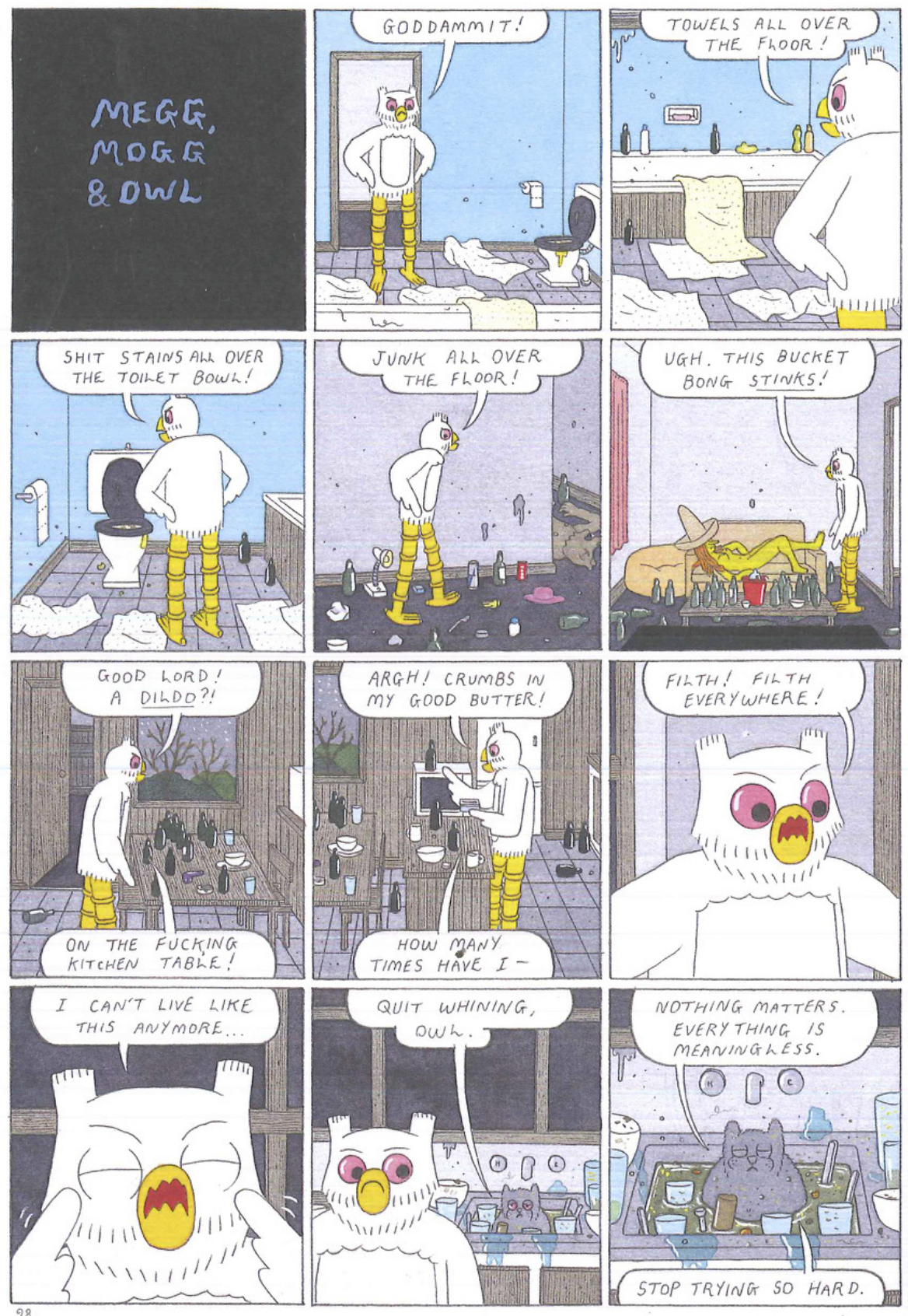

Fig. 3. Hanselmann, Simon. Megg \& Mogg in Amsterdam (And Other Stories). Fantagraphics, 2016. 98. Used by permission of Fantagraphics Books. 
partying. "What's wrong with you, Owl? It's fucking New Years!" says Werewolf Jones (195), and adds: "Wake the fuck up!" (195). The others convince him to join them for cocktails, but it's just another prank; they've made him cocktails that feature rum and urine (196). "What's wrong with you, Owl? Aren't you mad?" says Megg, when the joke is revealed (197). "Depressingly," says Owl, "I'm accustomed to such treatment at this point” (197).

Just as time the reader spends with Megg reveals growing dissatisfaction with her male-dominated friendship group, her relationship with Mogg, and her dependence on drugs, time spent with Owl reveals severe problems that are at first covered up by his normative behaviours. He is promiscuous for reasons that seem based in addiction rather than pleasure; he acquires STDs; he is alcoholic to the point that he seeks treatment from Alcoholics Anonymous meetings. What Megg seems to know, for herself, implicitly Owl says, for himself, explicitly. Approaching thirty, he says: "I need to make some changes in my life. Things can't go on like this forever" (Hanselmann, Megahex 101). Finally, the main chronology ends with Owl moving out (Hanselmann, Megabex 204) (note that the following two collections also discussed in this article take place within this main chronology).

Although the literature of roguery appeals to the reader's appetite for the salacious, and grunge literature positions deviancy as a means of breaching "the stresses and strains of modern life" (Vernay 155), the Megg, Mogg and Owl stories invite the reader to consider rogue acts in a panoply of contexts, whose values change as characters change and time in the story progresses. Owl's decision to move out is not explicitly linked to the sexual assault, but the scene clearly repositions Megg, Mogg and Werewolf Jones's other pranks as occasions of harassment, bullying and assault. It suggests that while the rogue world of the sharehouse allows inhabitants the advantage of negotiating their own social rules, it also lacks the regulations and balances of the outside world, which is moderated by norms and laws.

\section{Conclusion: Flashing Back and Flashing Forward}

With a few notable exceptions published online and in short online pieces, the Megg, Mogg and Owl chronology ended in 2014 on the last page of Megahex, with Owl alone in the back of a taxi, moving out of the sharehouse. Since then, the two full-length books published by Fantagraphics have included antics, excursions and flashbacks that deepen, contradict and colour scenes within that chronology, rather than showing what life looks like for the characters beyond the macro-structure of the story. When Owl moves out, Megg says: “Owl! You can't go! You just can't! / We're 
a three person couple!” (Hanselmann, Megabex 204). It's not clear that the friendship can survive outside of cohabiting three-person coupledom, or that the couple can survive without the three-person friendship.

Online, Hanselmann assures readers that the scope of the narrative will expand and the form of this instance of contemporary rogue literature will keep changing to facilitate the expansion. For Hanselmann, One More Year (the title of the third volume in the series) means "one more year until I finally stop fucking around and start to take these characters' lives forward," "one more year of the same old garbage," "one more year until Werewolf Jones dies of an overdose and the shit really hits the fan" (qtd. in Brown, 2017).

Yet although the characters have begun to go rogue from the beats of the format, necessitating that the format will follow, the narrative has meanwhile circled back and become continually re-creative: changing its own dominant readings, problematizing its own orthodoxies, and asking the reader to follow along and catch up with its re-inscribed meanings. A text about funny animals in sharehouses becomes a text about growing up and responding to trauma.

\section{Works Cited}

Brown, Hillary. "Cartoonist Simon Hanselmann Revisits the 'MinimumSecurity Torture Chamber' of High School in One More Year.” Pastemagazine.com. Paste 13 Jun. 2017. Web. 30 Jan. 2018.

Collins, Sean T. "Disgusting Creatures': The Simon Hanselmann Interview." Tcj.com. The Comics Journal 6 Jun. 2013. Web. 30 Jan. 2018.

Didion, Joan. The White Album. New York: Macmillan, 1990. Print.

Eco, Umberto. “The Myth of Superman.” Trans. Natalie Chilton. Diacritics 2.1 (1972): 14-22. Print.

Griffin, Alex. "A Brief History and Short Future of the Imaginary Sharehouse." Voiceworks 104 (2016): 19-25. Print.

Hanselmann, Simon. Megahex. Seattle: Fantagraphics, 2014. Print.

---. Megg \& Mogg in Amsterdam (And Other Stories). Seattle: Fantagraphics, 2016. Print.

---. One more year. Seattle: Fantagraphics, 2017. Print.

Kleparski, Grzegorz A., and Anna M. Pietrzykowska. "Elizabethan Rogue Literature.” Studia Anglica Resoviensia 2 (2001): 122-31. Print.

Leishman, Kirsty. "Australian Grunge Literature and the Conflict between Literary Generations.” Journal of Australian Studies 23.63 (1999): 94102. Print. 
Mayall, David. "Egyptians and Vagabonds: Representations of the Gypsy in Early Modern Official and Rogue Literature." Immigrants E Minorities 16.3 (1997): 55-82. Print.

Murrie, Linzi. "Changing Masculinities: Disruption and Anxiety in Contemporary Australian Writing." Journal of Australian Studies 22.56 (1998): 169-79. Print.

Nadel, Dan. "A Conversation with Simon Hanselmann." Tcj.com. The Comics Journal 7 Jul. 2017. Web. 30 Jan. 2018.

Nicoll, Helen, and Jan Pienkowski. Meg and Mog. London: Puffin, 1972. Print.

Randle, Christopher. "Glamorously Housebound: An Interview with Simon Hanselmann.” Hazlitt.net. Hazlitt 3 Jun. 2015. Web. 30 Jan. 2018.

Reith, James. "Simon Hanselmann: 'I Hate Twee Art. Life is Not Nice." Theguardian.com. Guardian 14 Apr. 2016. Web. 30 Jan. 2018.

Salgādo, Gāmini. The Elizabethan Underworld. Stroud: Sutton, 1984. Print. Vernay, Jean-François. "Sex in the City: Sexual Predation in Contemporary Australian Grunge Fiction." Journal of the Australasian Universities Language and Literature Association 2007.107 (2007): 145-58. Print.

Ronnie Scott is Lecturer in Creative Writing at RMIT University, where his research interests include independent publishing, queer fictions, new forms of nonfiction and Australian comics 1980-present. In 2007 he founded The Lifted Brow, an independent literary magazine. $\mathrm{He}$ is the author of a Penguin Specials Salad Days, and his first novel The Adversary will be published in April 2020.

ronnie.scott@rmit.edu.au 